by the schools under the supervision of the examining bodies.

The second session, on "School Examinations", was opened by Dr. T. L. Ibbs (University of Birmingham), who agreed with many of the points in Mr. Brereton's paper. He regretted some of the recent alterations in school examinations, particularly the abolition of the distinction mark, which had been a help to universities in selecting entrants although it reflected the proficiency of a school's coaching as well as the promise of a candidate. Mr. E. W. Tapper (Dulwich College) described the organization of the internal examinations at Dulwich, which are conducted in the atmosphere of a public examination and give the pupils some training in examination technique-an art that can and should be taught. Mr. W. B. Chivers (King Edward's Grammar School, Aston, Birmingham) spoke on practical examinations. He urged that separate papers should be set for 'advanced' and 'scholarship' candidates, that the marks should be assessed apart from the theory papers, and that the result of the practical examination should be recorded on the certificate. Many boys have outstanding practical gifts, and little aptitude for theory; there is a demand for these gifts in many industrial careers, and the certificate should state them. The difficulties of staging a practical examination for many candidates, with limited space and resources, were recalled with great good humour.

Prof. W. E. Curtis (president of the Institute of Physics) opened the discussion on these papers. He felt that there is little difference, as affecting university entrants, between the General Certificate of Education and the older form of examination, and endorsed Mr. Chivers's suggestions for improving the practical papers.

University examinations for honours students were the subject of the third session. Prof. Curtis said that the usual written examination lays too much stress on memory, and leaves too little time for thinking; it also leads the undergraduate to adopt wrong methods of study aimed at forecasting likely questions. He described the system used in the University of Durham at King's College during the honours course for developing and testing the student's powers of original thinking, and resource in practical work. Dr. J. G. Wilson (University of Manchester) said that the final honours examination tests a man's fitness to enter the profession of physics. Apart from the qualities mentioned by earlier speakers, one important skill is his ability to communicate his knowledge. Many good students have a poor command of English ; is this a matter to be rectified at school, or at the university? Little originality can be expected in specialized branches of physics ; but students ought to be able to apply their knowledge of the elementary ground-work of physics in an original way, and examination questions could be framed so as to test this ability.

The discussion centred first on Dr. Wilson's point about the low quality of written English prevalent among science students. Mr. R. Stone (Manchester Grammar School) said that this is a matter for the universities; the good scientist is often a "late developer' in English, and can quickly be trained in this when the time is ripe. Dr. H. R. Lang (secretary of the Institute of Physics) said that the real need is a command of functional English, an ability to write clear and concise reports. Returning to the main subject, Dr. J. Topping and Dr. R. Fürth spoke of the Continental system of oral examinations as perhaps a better way of assessing candidates but less favoured by candidates themselves.

University examinations also occupied the final session. Dr. W. H. Taylor (University of Cambridge) described the aims and organization of the practical examinations in physics for the Natural Sciences Tripos, and Dr. A. J. Woodall (Military College of Science, Shrivenham) spoke of examinations in physics for the non-specialist, quoting some very simple questions which could be set to test a candidate's grasp of elementary principles, and which did indeed cause his hearers some moments of hard thinking.

All the speakers were concerned with the use of examinations as a part of the technique of education, and this positive and constructive attitude was evident throughout the discussions. A valuable feature of the conference was the exchange of views and experiences between teachers and examiners of physies at all academic levels. G. R. Noakes

\section{ASLIB AERONAUTICAL GROUP CONFERENCE AND ANNUAL GENERAL MEETING}

$T$ HE Aslib Aeronautical Group held its first conference and annual general meeting at the College of Aeronautics, Cranfield, during April 5-7. The forty-eight delegates represented many aircraft and accessory manufacturers, airlines, experimental establishments and other bodies interested in the supply and use of aeronautical information. They were welcomed to the College by Air Chief Marshal Sir Edgar Ludlow Hewitt, chairman of the board of governors, and Air Marshal Sir Victor Goddard, principal of the College.

The programme included a talk by Mr. P. L. Taylor on electrical engineering as applied to aircraft, and Mr. A. H. Holloway (Technical Information Bureau) and Mr. J. G. Ogg (Central Radio Bureau) outlined the scope and functions of their respective departments in the Ministry of Supply.

The Group was fortunate in having as its guests Dr. A. C. de Kock and Dr. R. Timman, both of the Nationaal Luchtvaartlaboratorium, Holland, and co-authors of the N.L.L. scheme for the analytical cataloguing of wind-tunnel and other empirical aerodynamic data (NLL Report F64). One of the three working parties recently formed by the Group had been asked to examine the scheme in detail, and at the meeting it presented its interim report. General reactions were favourable: it was agreed that normal library classification systems are unsuitable for this special purpose, and the Dutch index cards, each giving an illustrated analysis of one scientific report, would be generally acceptable provided that minor improvements can be made in the physical process of selection. It was suggested that edge-notched or punched cards might be used.

The working party dealing with abstracts, in its interim report, outlined the steps taken to ascertain requirements for aeronautical abstracting services. This has been done by distributing with Index Aeronauticus seven hundred copies of a questionnaire. Replies indicate that present needs can be met by some improvement in the Index Aeronauticus itself rather than by the initiation of a new venture. 
The third working party, that engaged on periodicals, reported that considerable progress has been made in the preparation of a union catalogue listing the holdings of each aeronautical library. This is already facilitating loans and exchanges between libraries, and might later result in the co-operative purchase of periodicals for which only a small demand exists.

I'he programme of official meetings concluded with a general discussion on the need for uniformity in classification and in methods generally. There was a suggestion that abstract cards, suitable for use in a standard $5 \mathrm{in} . \times 3 \mathrm{in}$. card index, should be issued as part of R.A.E. reports: this received enthusiastic support, particularly from librarians who use the Universal Decimal Classification adopted some years ago by the Ministry of Supply.

The morning of April 7 was spent in a conducted tour of the College Departments, including those of Aerodynamics, Design and Propulsion, and the sections dealing with Standards and Business Systems.

The Aslib Aeronautical Group intends to hold further week-end meetings of this nature. Those interested should write to the honorary secretary, Mr. C. W. Cleverdon, Librarian, College of Aeronautics, Cranfield, Bletchley, Bucks.

\section{SMITHSONIAN INSTITUTION}

\section{ANNUAL REPORT FOR 1950-51}

$\mathrm{T}$

HE report of the Secretary of the Smithsonian Institution for the year ended June 30, 1951*, with which is included the financial report of the executive committee of the Board of Regents, refers to the deferment of some of the Institution's longterm programmes, such as modernization of museum exhibits, construction of urgently needed new buildings, and purchase of modern instruments and laboratory equipment, caused by the curtailment of Government spending since the Korean crises. The position is the more serious because the annual number of visitors is rapidly approaching three millions, and the increase of the collections in the fields of natural history, industry, history and aeronautics has long since crowded all available storage space. The Adams-Clement collection, one of the most important historically to come to the Institution in recent years, was formally opened in April. Accessions to the National Museum during the year totalled 303,000 , including further archæological material from Neolithic sites in Honshu, Japan, many mammals, birds and marine invertebrates from Labrador and Newfoundland, a comprehensive collection of fishes, crustaceans, molluscs and miscellaneous invertebrates from the Gulf of Mexico, several important collections of insects and more than 16,500 plants in exchanges with other institutions, and a collection of historical electronic and electrical apparatus. Field-work was conducted by the staff in Cuba, Panama, Costa Rica, Honduras, Colombia, South Africa, Southern Rhodesia, British North Borneo and many parts of the United States.

The director of the Bureau of American Ethnology continued his archæological work on the Atlantic

* Report of the Secretary of the Smithsonian Institution and Financial Report of the Executive Committee of the Board of Regent for the Year ended June 30, 1951. (Pub. 4056.) Pp. ix +160. (Washington, D.C.: Government Printing Office, 1952.) 55 cents. coast of Panama, and a second season of field-work on Cornwallis Island in the Canadian Arctic yielded a large collection of the Thule culture material. The first five volumes of the "Arctic Bibliography" on which the Arctic Institute has been engaged for the past five years were completed and delivered to the Government Printing Office, Washington, D.C. The collection of the first volume of River Basin Surveys papers was also completed; since the beginning of this field-work 2,894 archæological sites have been located and recorded, of which 545 have been recommended for excavation or additional testing. The excavation work during the year covered twenty reservoir areas in ten States, and the work of the twenty-six excavating parties is described in considerable detail in the appended report on the Bureau. The Institute of Social Anthropology continued its research and teaching programme in Brazil, Colombia, Guatemala, Mexico and Peru.

The International Exchange Service handled the record number of 1,011,000 packages of publications, an increase of 1,375 , although the actual weight decreased. No shipments were made to China or Rumania. One hundred and two sets of United States official publications are now supplied to other countries in exchange for similar publications, sixtyone of these being full sets, while eighty-five copies of the Federal Register and ninety-two of the Congressional Record are also supplied. A list of repositories is included in the report. The National Zoological Park, which received some $3,460,400$ visitors during the year, housed 2,813 animals at the end of the year, additions of 1,768 balancing the losses and removals of 1,776. The Astrophysical Observatory continued its studies of solar radiation at the high-altitude stations at Table Mountain, in California, and at Montezuma, Chile, and at the former a method is being developed for determining ozone in the upper atmosphere by spectrobolometric measurements. Some work was done on the improvement of the melikeron for measuring outgoing radiation, and two silver-disk pyrheliometers were under construction. The Division of Radiation and Organisms has begun a series of biochemical investigations of photomorphogenesis in green plants. Thirty-three scientific workers used the facilities for biological research at the Barro Colorado Island station.

\section{ADVANCES IN PHYSICS \\ A NEW QUARTERLY JOURNAL}

$T$ HE long-established Philosophical Magazine needs no recommendation to mathematicians and physicists, and any new venture under the auspices of this journal is sure to be of high standard and most welcome. Advances in Physics*, the new quarterly supplement of the Philosophical Magazine, has for its purpose the publication of articles which are written by experts for experts, and in which topics of current interest in physics, covering theoretical and experimental aspects in addition to certain branches of applied mechanics, are reviewed. In order not to clash with similar, though annual, periodicals such as Reports on Progress in Physics of the Physical Society, the contributions to Advances

*Advances in Physics. A Quarterly Supplement of the Philosophical Magazine. 1, No. 1 (January 1952). Pp. iv +110 . (London: Taylor and Francis, Ltd.) 158 ., or 558 . a year. 